\title{
がんターゲティング療法の最前線
}

\author{
宇都口直樹, ${ }^{*}, a$ 平 $\quad$ 裕一郎 $b$
}

\section{Forefront of Cancer Targeting Therapy}

\begin{abstract}
Naoki Utoguchi ${ }^{*, a}$ and Yuichiro Taira ${ }^{b}$
${ }^{a}$ Department of Pharmaceutics and Biopharmaceutics, Showa Pharmaceutical University; 3-3165 Higashitamagawagakuen, Machida, Tokyo 194-8543, Japan: and bepartment of Pharmaceutical Sciences, Teikyo
\end{abstract} Heisei University; 4-21-2 Nakano, Nakano-ku, Tokyo 164-8530, Japan.

がんはわが国において，現在死因第 1 位の疾患で あり，その治療法は外科療法，放射線療法，化学療 法に大別される。これら療法は，それぞれに長所， 短所を有する. 薬学において, その研究の中心は化 学療法であるが，多くの抗悪性腫瘍薬では重篤な副 作用の発生が報告されており，副作用により治療を 中断せざるを得ないケースが多々ある。したがっ て，切れ味の鋭い新規抗悪性腫瘍薬の開発は急務の 課題である. その中で，がんターゲティング療法は， drug delivery system により正常組織への影響を低 減しつつ，がん組織を集中的に治療するものであ り, 作用増強, 副作用軽減の面から期待されている 方法論である.

がんターゲティング療法は当初, 特異性の高さか ら，抗体をキャリアとしたいわゆる「ミサイル療法」 が期待され，多くの研究がなされた。すなわち，が 几細胞に特異的な抗体に抗悪性腫瘍薬やトキシンを 結合させたイムノコンジュゲートである. しかし， がん細胞特異抗原が少ないことから, 本アプローチ は，一部のがん種でしか実用化に至っていない。そ こで，がんターゲティング療法の別の基本戦略とし て微粒子ナノキャリアを用いたものが注目されるこ ととなった. 約 100-200 nm 程度のナノサイズの微 粒子は，正常組織の血管内皮細胞層は細胞間隙が密 であり，血管壁を透過することができないが，一 方，腫瘍組織の血管内皮細胞層は細胞間隙が大き

a昭和薬科大学薬剤学研究室（T194-8543 東京都町田 市東玉川学園 3-3165), b帝京平成大学薬学部（T1648530 東京都中野区中野 4-21-2)

*e-mail: utoguchi@ac.shoyaku.ac.jp

日本薬学会第 137 年会シンポジウム S32 序文
く，血管壁を透過する．またリンパ脈管が不完全で あり，透過した微粒子が血管外に留まる。このよう な現象は enhanced permeability and retention effect (EPR 効果) と呼ばれ，微粒子ナノキャリアの腫瘍 選択的な集積を可能にしている。この EPR 効果に 基づくがんターゲティング療法は，実用化された製 剂もあるが，現状，まだ多くの製剤が発売されてい るわけではない.

一方, 近年, 抗体医薬や分子標的薬の進歩は極め て速く，かつ重要なものとなっている．2015 年に おける抗悪性腫瘍薬の売り上げランキングは上位 5 位までが抗体医薬と分子標的薬で占められている. 抗体医薬と分子標的薬以外の抗悪性腫瘍薬は全医薬 品売上中 25 位以内に入るものもないのが現状であ る. 現在, 治験段階の抗体医薬 - 分子標的薬も多 く, がん化学療法の中心が抗体医薬・分子標的薬で あることはしばらく続くと考えられるが，がん治療 の標的分子も出尽くされた感があり，これからは全 く異なったアプローチのがんターゲティング療法の 開発を起点とする, 新しいブレークスルーが期待さ れる。

そこで, 本シンポジウムでは, 全く新しい戦略に 基づくがんターゲティング療法研究の最前線を紹介 することとした，長野先生らには，プロテオミクス を駆使した標的分子の検索基盤技術の創製に関する ご講演をお願いした。 具体的には, 候補タンパク質 の網羅的な検証と効率的な絞り込みを可能とする抗 体プロテオミクス技術の開発であり，本技術開発に より, 乳がんのターゲティング療法に資する創薬 ターゲットの発見に成功された。長崎先生には従来 の低分子活性酸素除去剤の問題であった生体にとっ 
て必要な活性酸素種に影響を与えず，疾病に関与す る活性酸素を除去する新規抗酸化ナノ粒子を薬物 キャリアとした，がん治療法の開発に関してご講演 をお願いした。本キャリアは抗悪性腫瘍薬の副作用 軽減にも有効であり, 従来の抗悪性腫瘍薬が副作用 発現により治療を中断せざるを得ないケースの改善 に大きく寄与できるものと考えられる．鈴木先生ら には超音波エコーガスを封入したナノバブルと超音 波を利用したがんセラノスティクス（診断・治療シ ステム）の構築に関するご講演をお願いした．本シ ステムは，弱い超音波を照射し，まずがんの部位を 診断し，そこに強い超音波を照射し，ナノバブルの 圧壊現象により治療を同時に可能とする画期的なシ ステムである. 小泉先生らには，アデノウイルス由 来のタンパク質を用いたがんターゲティング療法の ご講演をお願いした．ウイルスの特性である細胞へ の感染機構を利用したがんターゲティングへの応用
である，残念ながら，本総説にはご執筆頂けなかつ たが，関連する文献等を参照されたい，平先生らに は，嫌気性細菌であるビフィズス菌ががん組織に集 積する性質を利用したがん治療法についてのご講演 をお願いした。 ビフィズス菌の特性を巧みに利用し た治療法というだけでなく，本方法は，抗体医薬と は違い，極めて安価かつ大量に簡便に生産すること が可能であり，抗体医薬主流の現在のがん夕ーゲ ティング療法の方向性を変える大きなポイントとな る可能性を秘めている.

化合物だけではなく，超音波といつた物理的手法 や細菌，ウイルスなど生物が有する特徵的な機能を 利用するといつた極めてユニークな手法によるがん ターゲティング療法研究の先駆者が一堂に会し, 参 加者とともに議論することで, 新たなターゲティン グ療法の進歩につながることを期待する. 